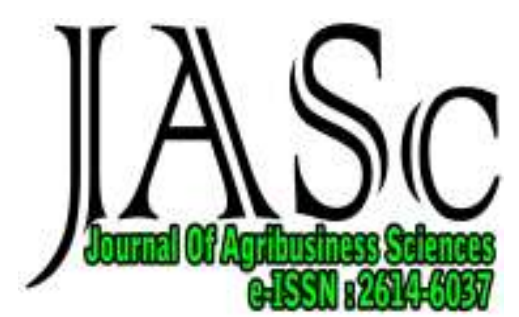

Oktober 2017 Volume 01 No. 01

\title{
SOCIAL CAPITAL REVIEW ON VEGETABLE FARMING (CASE STUDY AT BAROKAH FARMER GROUP SUB-DISTRICT OF TANAH ENAM RATUS SUB DISTRICT OF MEDAN MARELAN)
}

\author{
KAJIAN MODAL SOSIAL PADA USAHA TANI SAYUR \\ (STUDI KASUS PADA KELOMPOK TANI BAROKAH \\ KELURAHAN TANAH ENAM RATUS KECAMATAN MEDAN MARELAN)
}

\author{
Mailina Harahap, Surna Herman \\ Fakultas Pertanian Universitas Muhammadiyah Sumatera Utara \\ E-mail: ummi_ahsan@yahoo.co.id
}

\begin{abstract}
Social capital that existed in the community to grow and develop along with the development of human.Modal social built in the interaction of farmers in the container farmer group is a capital that continues to undergo change.Dengan dynamics of vegetable farmers in carrying out farm activities can not be separated from the capital social is built on the life of vegetable farmers. This study aims to find out how social capital contained in vegetable farmers who can be reviewed from the aspect; the farmer's active participation, farmer's belief, social norm and responsibility. Samples of research are vegetable farmer in Barokah Farmer Group of Land Land of Six Ratus.Penelitian use primary data obtained from direct interview with respondent and secondary data. Method of data analysis is tabulation and descriptive analysis by tabulating the frequency of elements of social capital under study. The result of the research shows that all aspects analyzed in social capital consisting of active participation, trust, social norm and dominant responsibility are high. Thus the social capital contained in the Barokah farmer group which is a research sample is a social capital that builds for agricultural development in the research location.
\end{abstract}

Keywords: Social Capital, Farming, Vegetable, Farmer Group

\section{ABSTRAK}

Modal social (social capital) yang terdapat pada masyarakat tumbuh dan berkembang seiring dengan perkembangan manusia.Modal social yang terbangun pada interaksi petani dalam wadah kelompok tani merupakan modal yang terus mengalami perubahan.Dengan demikian kedinamisan petani sayur dalam melaksanakan kegiatan usaha tani tidak terlepas dari modal social yang terbangun pada kehidupan petani sayuran.Penelitian ini bertujuan untuk mengetahui bagaimana modal social yang terdapat pada petani sayur yang dapat di tinjau dari aspek; partisipasi aktif petani, kepercayaan petani, norma social dan tanggung jawab.Sampel penelitian adalah petani sayur dalam Kelompok Tani Barokah Kelurahan Tanah Enam Ratus.Penelitian menggunakan data primer yang diperoleh dari wawancara langsung dengan responden dan data sekunder.Metode analisis data adalah tabulasi dan analisis deskriptif dengan membuat tabulasi frekuensi dari unsur modal social yang diteliti. Hasil hasil penelitian menunjukkan bahwa seluruh aspek yang di analisis pada modal social yang terdiri dari partisipasi aktif, kepercayaan, norma social dan tanggung dominan adalah tinggi. Dengan demikian modal social yang terdapat pada kelompok tani Barokah yang merupakan sampel penelitian merupakan modal social yang membangun untuk pengembangan pertanian di lokasi penelitian.

Kata Kunci: Modal Sosial, Usahatani, Sayur, Kelompok Tani

\section{A. PENDAHULUAN}

Sektor pertanian memegang peranan penting dalam menunjang pembangunan berkelanjutan.(sustainable development). Dengan adanya ketergantungan kegiatan agroindustridan komoditi primer produk pertanian yang dijadikan sebagai bahan baku, berimplikasi pada keterkaitan sumberdaya manusia dengan sumberdaya alam dan lingkungan. Sektor pertanian yang dikelola secara benar dan optimal akan menghasilkan komoditi pertanian berkualitas. Produk Indonesia yang memiliki daya saing, akan mampu bersaing pada pasar global. Dan kegiatan tersebut akan berkelanjutan dengan semakin berkembangnya kegiatan sektor pertanian yang memperhatikan aspek jangka panjang.

Pembangunan nasional secara keseluruhan tidak terlepas dari pembangunan pertanian. Dengan kata lain, konsep pembangunan menempatkan pembangunan pertanian sebagai mesin penggerak utama (prime mover) perekonomian nasional. Sektor pertanian memiliki peran trategis dalam menyediakan 
lapangan kerja dan memanfaatkan sumberdaya alam untuk menopang kebutuhan hidup manusia.Selanjutnya sektor pertanian juga memberikan kontribusi terhadap Produk Domestik Bruto (PDB). Pada tahun 2010 Sektor pertanian menempati peringkat ke-2 memberikan kontribusi terhadap PDB yaitu sebesar Rp. 239,4 triliun setelah sektor industri pengolahan sebesar Rp380,9 triliun. ${ }^{1}$

Sayuran merupakan salah satu jenis hortikultura yang setiap hari dikonsumsi oleh banyak orang.Permintaan konsumen terhadap sayuran semakin meningkat seiring dengan meningkatnya kesadaran manusia terhadap kesehatan.Pada sayuran terdapat sumber vitamin danmineralyang sangat penting untuk memenuhi asupan gizi manusia.Maka permintaan sayur baik domestik dan global memberikan peluang Indonesia untuk meningkatkan produksi sayuran.Khususnya untuk pasar global Indonesia harus mampu menghasilkan komoditi sayuran yang berkualitas dan berdaya saing.

Modal social (social capital) yang terdapat pada masyarakat tumbuh dan berkembang seiring dengan perkembangan manusia.Demikian pula modal social yang terdapat pada petani sayuran di Kelurahan Tanah Enam Ratus Kecamatan Medan Marelan yang merupakan salah satu sentra produksi sayuran yang berada di Kota Medan. Usahatani sayur petani di kelurahan Tanah Enam Ratus perlu untuk di kembangkan sebagaimana penelitian Endang dan Harahap, Mailina untuk itu hal pertama yang perlu diperhatikan untuk meningkatkan daya saing petani adalah bagaimana merubah cara berfikir petani terhadap koperasi dan kelompok tani. ${ }^{2}$ Dalam konteks demikian modal social memiliki peran penting. Sebagaimana penelitian Wuysang ${ }^{3}$ menyatakan bahwa modal social kelompok tani adalah merupakan aset, nilai dan usaha kelompok tani yang didasarkan pada kepentingan, kesamaan kondisi lingkungan (social, ekonomi, sumberdaya) yang turut menentukan pengembangan aktivitas kelompok tani.

Modal social yang terbangun pada interaksi petani dalam wadah kelompok tani merupakan modal yang terus mengalami perubahan.Dengan demikian kedinamisan petani sayur dalam melaksanakan kegiatan usaha tani tidak terlepas dari modal social yang terbangun pada kehidupan petani sayuran. Sebagaimana Wuysang 3 menyatakan bahwa modal social pada intinya adalah serangkaian nilai dan norma yang merupakan wujud nyata dari suatu institusi yang bersifat dinamis. Selanjutnya beliau menambahakan bahwa wujud nyata dari modal social dalam kelompok tani ditunjukkan dalam bentuk kepercayaan, jaringan social, tanggung jawab dan kerjasama.
Kepercayaan merupakan karakteristik pertama yang harus terdapat pada sebuah kelompok.Fukuyama mengemukakan bahwa kepercayaan adalah sikap yang saling mempercayai sehingga memungkinkan masyarakat untuk saling bersatu dengan yang lain dan memberikan kontribusi pada peningkatan modal sosial. ${ }^{4}$ Sementara Putnam menjelaskan bahwa trust atau rasa salign percaya adalah bentuk keinginan mengambil resiko dalam hubungan sosial yang didasari oleh munculnya perasaan yakin terhadap individu lain akan melakukan sesuatu sebagaimana yang diharapkan dan akan selalu pada tindakan yang saling mendukung dan tidak akan melakukan tindakan yang merugikan diri sendiri maupun kelompok. ${ }^{5}$ Pada kepercayaan antar manusia terdapat tiga hal yang saling terkait, yaitu: 1).Hubungan sosial anatar dua orang atau lebih, termasuk dalam hubungan ini adalah institusi yang dalam hal ini adalah orang atau individu. 2).Harahapan yang akan terkandung dalam hubungan itu, jika direalisasikan akan memberikan kerugian pada salah satu individu atau kedua belah pihak dan 3).Interaksi sosial yang memungkinkan hubungan dan harahapn terwujud.

Jaringan sosial akan terbentuk dengan adanya interaksi antara satu individu dalam suatu kelompok dan bisa juga terjadi antara satu kelompok dengan kelompok lain. Setiap individu yang merupakan makhluk sosial tidak pernah terlepas dari berinteraksi dengan individu yang lain. Jaringan sosial yang terbentuk pada kelompok masyarakat merupakan dari implikasi modal sosial yang terdapat pada masyarakat. Desi Utami mengemukakan bahwa modal sosial tidak dibangun hanya oleh satu individu melainkan terletak pada kecenderungan yang tumbuh dalam suatu kelompok untuk bersosialisasi sebagai bagian penting dari nilainilai yang melekat. ${ }^{6}$ Modal sosial terletak pula pada kemampuan sekelompok orang dalam suatu asosiasi atau perkumpulan dalam melibatkan diri dalam suatu jaringan hubungan sosial. Modal sosial yang kuat tergantung pada kapasitas yang ada dalam kelompok masyarakat untuk membangun sejumlah asosiasi untuk membangun jaringan sosial.

Jaringan sosial pada modal sosial dapatlah dikatakan sebagai ikatan yang menghubungkan antar individu yang memberikan adanya kerjasama dan keterikatan yang kuat dengan adanya aturan dan norma-norma yang di buat bersama untuk tujuan bersama.Sifat dari jaringan sosial adalah; 1).Jaringan sosial harus diukur dengan fungsi ekonomi dan fungsi kesejahteraan sosial.Fungsi ekonomi menunjukkan produktivitas, efisiensi, efektifitas yang tinggi, sedangkan fungsi sosial menunjukkan dampak 
partisipatif, kebersamaan yang diperoleh pada kegiatan ekonomi. 2).Jaringan sosial harus memiliki sifat keterbukaan pada semua orang untuk memberikan kesempatan kepada public. 3). Jaringan sosial harus mengandung kombinasi fungsi ekonomi dan sosial yang terdapat pada modal sosial yang bersifat integrative.

Norma social merupakan sekumpulan aturan yang diharapkan dipatuhi dan diikuti oleh masyarakat dalam suatu entitas sosial tertentu. Aturan-aturan ini biasanya terinstitusionalisasi, tidak tertulis tapi dipahami sebagai penentu pola tingkah laku yang baik dalam konteks hubungan sosial sehingga ada sangsi sosial yang diberikan jika melanggar. Norma sosial akan menentukan kuatnya hubungan antar individu karena merangsang kohesifitas sosial yang berdampak positif bagi perkembangan masyarakat. Oleh karenanya norma sosial disebut sebagai salah satu modal sosial.

Norma-norma yang ada pada sebuah pranata dapat terbentuk secara sengaja maupun secara tidak sengaja. Norma-norma yang ada di dalam masyarakat mempunyai kekuatan mengikat yang berbeda-beda, ada yang lemah dan ada pula yang kuat ikatannya. ${ }^{7}$.Norma-norma tersebut di atas akan mengalami suatu proses seiring dengan perjalanan waktu dan pada akhirnya normanorma itu akan menjadi bagian tertentu dan pranata sosial. Soekanto mengatakan proses itu disebut dengan istilah institutionalization atau proses pelembagaan, yaitu suatu proses yang dilewati oleh suatu norma yang baru untuk menjadi bagian dari salah satu pranata sosial. Pranata sosial dianggap sebagai peraturan apabila norma-norma tersebut membatasi serta mengatur perilaku orang-orang di dalam lingkungan pranata itu berada. 7 Proses pelembagaan sebenarnya tidak berhenti demikian saja, akan tetapi dapat berlanjut lebih jauh lagi hingga suatu norma kemasyarakatan tidak hanya melembaga saja dalam kehidupan masyarakat, namun telah Tabel 1. Potensi Pertanahan Pertanian Sayuran di Kecamatan Medan Marelan

\begin{tabular}{llc}
\hline No. & \multicolumn{1}{c}{ Kelurahan di Kecamatan Medan Marelan } & Luas Pertanahan Sayuran (Ha) \\
\hline 1. & Labuhan Deli & 6 \\
2. & Rengas Pulau & 99 \\
3. & Terjun & 152 \\
4. & Tanah Enam Ratus & 196 \\
5. & Paya Pasir & 12 \\
\hline
\end{tabular}

Sumber: Kantor Camat Medan Marelan, 2006

\section{Jenis dan Sumber Data Penelitian}

Jenis data yang digunakan pada penelitian adalah data kuantitatif dan data kualitatif.Adapun data kuantitatif adalah data yang berbentuk angka dan data kualitatif adalah data dalam bentuk kalimat-kalimat.Sumber data yang digunakan pada penelitian terdiri dari data primer dan data sekunder. Data primer diperoleh secara langsung dari lokasi penelitian dengan metode wawancara. Adapun data sekunder yang akan mendukung penelitian menginternalisasi di dalam kehidupannya. Norma hukum pada dasarnya bertujuan untuk mencapai kedamaian hidup bersama, yang merupakan keserasian antara ketertiban dan ketentraman.

Keinginan yang kuat dari anggota kelompok untuk tidak saja berpartisipasi tetapi senantiasa mencari jalan bagi keterlibatan anggota kelompok dalam suatu kegiatan masyarakat. Anggota kelompok melibatkan diri dan mencari kesempatan yang dapat memperkaya hubungan-hubungan sosial dan menguntungkan kelompok. Perilaku inisiatif dalam mencari informasi berbagai pengalaman, memperkaya ide, pengetahuan, dan beragam bentuk inisiatif lainnya baik oleh individu mapun kelompok, merupakan wujud modal sosial yang berguna dalam membangun masyarakat. Berdasarkan uraian tersebut, penelitian ini bertujuan untuk mengetahui bagaimana modal social yang terdapat pada petani sayur yang dapat di tinjau dari aspek; partisipasi aktif petani, kepercayaan petani, norma social dan tanggung jawab.

\section{B. METODE PENELITIAN \\ MetodePenelitian}

Metode penelitian yang digunakan adalah metode studi kasus (Case Study) yaitu penelitian yang dilakukan dengan melihat langsung kelapangan. Karena study kasus merupakan metode yang menjelaskan jenis penelitian mengenai suatu objek tertentu selama kurun waktu, atau suatu penomena yang ditemukan pada suatu tempat yang belum tentusama dengan daerah lain.

\section{Metode Penentuan Lokasi Penelitian}

Daerah penelitian ditentukan secara sengaja (purposive) dengan memperhatikan bahwa Kelurahan Tanah Enam Ratus merupakan salah satu sentra pertanian komoditi holtikultura khususnya sayuran yang berada di kota Medan. Sebagaimana pada Tabel 1. 


\section{MAILINA HARAHAP, SURNA HERMAN}

populasi adalah sampel penelitian yang berjumlah 30 petani sayur.

\section{Metode Pengumpulan Data Penelitian}

Pengumpulan data penelitian dilakukan dengan metode observasi dan metode wawancara. Metode observasi adalah pengumpulan data dengan pengamatan secara langsung terhadap kondisi lokasi penelitian dan responden penelitian yaitu petani kelompok tani sayuran Kecamatan Medan Marelan. Adapun metode wawancara adalah pengumpulan data melalui wawancara langsung kepada responden penelitian dan pihak terkait.

\section{Metode Analisis Data}

Teknik analisis yang digunakan untuk menjawab permasalahan penelitian adalah data diolah secara tabulasi dan dilanjutkan dengan Tabel 2. Karakteristik sampel penelitian

\begin{tabular}{llc}
\hline No. & Keterangan & Rata-rata \\
\hline 1. & Umur responden (tahun) & 47 \\
2. & Pendidikan formal responden (tahun) & 5 \\
3. & Pengalaman bertani responden (tahun) & 21 \\
4. & Jumlah tanggungan responden (jiwa) & 4 \\
$\mathbf{5 .}$ & Luas lahan usaha tani sayur responden (Ha) & 0,27 \\
\hline & Sumber: Kantor Kelurahan Tanah Enam Ratus
\end{tabular}

\section{Umur Responden}

Pada tabel 2 diketahui bahwa rata-rata umur responden penelitian adalah 47 tahun. Dari rerata umur tersebut menjelaskan bahwa kegiatan usaha tani sayur yang dilakukan responden tidak lagi memiliki usia muda. Hal ini sebagaimana peneliti temukan ketika melakukan wawancara dengan responden bahwa jumlah petani sudah semakin berkurang.Bahkan kegiatan usaha tani pada umumnya tidak lagi dilakukan secara turun temurun.

Jarak Kelurahan Tanah Enam Ratus yang hanya lebih kurang $10 \mathrm{~km}$ ke pusat kota Medan memberikan implikasi meningkatnya permintaan lahan untuk dijadikan perumahan. Sehingga anak-anak petani banyak yang lebih tertarik untuk menjual lahan mereka dan melakukan pekerjaan di luar usaha tani sayur. Disamping itu rata-rata umur responden 47 tahun masih bisa dikatakan pada usia produktif di mana mereka masih memiliki kemampuan mengelola usaha tani sebagai mata pencaharian tetap maupun sampingan.

\section{Pendidikan Formal Responden}

Pendidikan merupakan aspek penting dalam pengembangan sumberdaya manusia.Peningkatan kualitas sumberdaya manusia dapat di lihat dari aspek pendidikan.Hal ini didasarkan bahwa dengan pendidikan maka seseorang memiliki kemampuan dalam pola pikir dan analisis secara deskriptif dengan menggunakan table ditribusi frekuensi berdasarkan scoring (skor).Adapun skala pengukuran dari jawaban responden menggunakan skala Likert yang di tentukan oleh empat pilihan jawaban yaitu; sangat setuju skor 4, setuju skor 3, tidak setuju skor 2 dan sangat tidak setuju skor 1 .

\section{HASIL DAN PEMBAHASAN}

\subsection{Karakterstik Responden Penelitian}

Sampel penelitian adalah petani yang tergabung pada kelompok Tani Barokah yang berjumlah 30 petani. Adapun kegiatan usaha tani yang dilakukan oleh petani sampel adalah usaha tani sayur yang terdiri dari sayur kangkung, sayur bayam dan sayur sawi manis. Karakteristik dari petani sampel dapat dijelaskan sebagaimana pada Tabel 2.
pengetahuan.Rata-rata pendidikan formal responden adalah 5 tahun yang artinya bahwa rata-rata responden penelitian tidak menyelesaikan pendidikan pada tingkat Sekolah Dasar (SD).

Tingkat pendidikan responden yang bisa dikatakan tidak tamat Sekolah Dasar (SD) menjadi kendala responden dalam menerima inovasi yang berkembang. Hal ini diketahui dari wawancara dengan beberapa responden yang mengemukakan bahwa mereka dalam kegiatan penyuluha sebenarnya kurang faham dengan apa yang disampaikan tetapi karena kekompakan petani kuat mereka turut berapartisipasi aktif. Maka untuk meningkatkan wawasan petani diperlukan kegiatan penyuluhan yang kreatif sebagai pendidikan non formal petani.

\section{Pengalaman Bertani Responden}

Pengalaman bertani responden adalah sudah berapa lama petani melakukan kegiatan usaha tani dalam tahun.Dari hasil penelitian diketahui sebagaimana pada tabel 2.pengalaman usaha tani sayur responden rata-rata 21 tahun. Dengan demikian dapat dikatakan bahwa responden sudah cukup lama dalam usaha tani sayur. Dengan kata lain bahwa responden memiliki pengetahuan dan wawasan yang cukup dalam kegitan usaha tani. Lamanya pengalaman responden dalam usaha tani sayur dapat juga di jelaskan dari rata-rata umur responden yaitu 47 tahun.Dengan umur tersebut menunjukkan 
bahwa responden memiliki pengalaman yang cukkup dalam kegiatan usaha tani.

Pengalaman yang cukup dalam usaha tani menunjukkan bahwa responden sudah banyak belajar dari pengalaman mereka dalam mengusahakan lahan pertanian sayur mereka. Baik dalam menyelesaikan persoalan pada kegiatan usaha tani seperti penyakit tanaman, terserang hama, turunnya harga sayur dan sebagainya.

\section{Jumlah Tanggungan Keluarga Responden}

Keluarga merupukan kumpulan dari ayah, ibu, anak dan jika ada tambahan dari kerabat atau sanak saudara yang hidup bersama.Adapun jumlah tanggungan yang dimaksud adalah anggota keluarga yang masih dibiayai oleh kepala keluarga. Jumlah tanggungan keluarga pada umumnya akan menjadi dasar bagi kepala rumahtangga dalam menghasilkan pendapatan rumahtangga. Hal ini disebabkan jumlah tanggungan yang besar akan berbanding lurus dengan pengeluaran rumahtangga. Dengan demikian akan diperlukan adanya pendapatan yang tinggi untuk bisa memenuhi pengeluaran ramahtangga.

Berdasarkan Tabel 2 dapat diketahui bahwa jumlah tanggungan responden rata-rata adalah 4 orang. Dari jumlah tanggungan tersebut sebagaimana diketahui umur responden rata-rata 47 tahun, pada umumnya responden penelitian memiliki anak yang sudah berkeluarga sehingga yang masih bersama satu rumah hanya 1 atau sampai 3 anak saja. Adapun keterlibatan anggota rumahtangga dalam kegiatan usaha tani sayur hanya pada kegiatan pemanenan dan penanaman sayuran sawi.Sementara untuk penanaman kangkung dan bayam mereka tidak perlu menambah tenaga kerja luar keluarga.Sehingga meskipun dengan rata-rata umur 47 tahun responden masih memiliki kemampuan dalam mengusahakan usaha tani sayur.

\section{Luas Lahan Usaha Tani}

Lahan merupakan salah satu faktor produksi pada kegiatan usaha tani responden.Lahan ataupun tanah yang diusahakan untuk kegiatan usaha tani sayur memiliki peranan penting dalam menentukan produksi sayur petani.Dengan kata laian lahan merupakan faktor produksi berubah artinya semakin luas lahan yang digunakan untuk usaha tani sayur makan semakin tinggi produksi sayur yang dihasilkan petani.

Kesuburan tanah juga merupakan aspek penting dalam menentukan produksi sayur. Secara fisik, tanah yang subur akan menghasilkan produksi sayur yang berkualitas dan dapat menekan biaya usaha tani dari sisi ekonommi. Untuk itu kesuburan tanah merupakan aspek yang harus diperhatikan dalam kegiatan usaha tani.Hal ini memperhatikan bahwa dalam penggunaannya tanah tidak selamanya mampu menghasilkan unsur hara yang produktif bagi tumbuhan. Sebagaimana yang dikemukakan oleh Hanafie (2010) bahwa produksi fisik dari tanah akan mengalami penurunan atau hukum kenaikan hasil yang semakin berkurang (the law of diminishing return).

Rata-rata luas lahan yang dimiliki petani sayur adalah 0,27 Ha.Dengan luas lahan tersebut menunjukkan bahwa kegiatan pertanian yang diusahakan responden masih dalam skala usaha tani kecil. Sebagaimana wawancara yang dilakukan pada umumnya responden mengemukakan hasil panen yang diperoleh hanya untuk membiayai kebutuhan hidup sehari-hari.Dan mereka sudah lama menjadikan kegiatan usaha taninya sebagai sumber mata pencaharian utama.

\subsection{Gambaran Usaha Tani Sayur Responden}

Kegiatan usaha tani responden adalah sayuran yang terdiri dari sayur Kangkung, Bayam, dan Sawi.Pada umumnya petani di lokasi penelitian melakukan pergantian tanaman sayur dengan manajemen usaha tani yang sederhana.Karena kegiatan usaha tani yang dilakukan adalah sebagai sumber mata pencaharian utama maka, petani melakukan pemanenan yang tidak pernah putus.Adapun manajemen yang mereka lakukan adalah dengan melakukan pergiliran penanaman sayur.Luas areal lahan usaha tani di bagi menjadi beberapa bagian dengan penanaman sayuran yang bertahap.Misalnya mingggu pertama petani menanam sayur kangkung selanjutnya minggu ke dua petani menanam sayur bayam.Minggu ke tiga sayur Kangkung kembali dan demikian selanjutnya.Sehingga pada setiap minggu petani melakukan panen sayur yang bergantian.

Budi daya yang dilakukan pada sayur Kangkung dan Bayam tidak berbeda. Adapun tahapan yang dilakukan adalah:

1. Pengolahan lahan

Pada proses pengolahan lahan petani melakukan penggemburan tanah yang selanjutnya tanah dibentuk bedengan. Sebelum di semai tanah yang sudah dibentuk bedengan diberikan pupuk kandang dari kotoran sapi atau ternak bebek.Petani di lokasi penelitian pada pengolahan tanah tidak perlu diberi campuran pupuk kimia.Menurut keterangan responden, tanah di lokasi penelitian masih terjaga tingkat kesuburannya.Setelah diberikan pupuk 
kandang bedengan tersebut dibiarkan satu minggu dan setiap sore di siram.

2. Penyemaian benih

Tanah bedengan yang sudah dibiarkan satu minggu untuk selanjutnya di lakukan penyemaian benih sayur Kangkung dan Bayam. Adapun cara penyemaiannya terlebih dahulu dibuat larikan untuk mengatur jarak tanam. Setelah benih disemai langsung dilakukan penyiraman benih.

3. Perawatan tanaman sayur

Setelah benih sayur Bayam dan Kangkung di semai selanjutnya dilakukan tahap perawatan yang terdiri dari penyiraman, penyiangan dan pengendalian hama. Penyiraman dilakukan setiap hari.Sedangkan penyiangan dilakukan untuk membersihkan bedengan dari rumput.Selanjutnya dilakukan pemupukan menggunakan pupuk kimia yaitu pupuk Urea.

4. Pemanenan

Setelah Bayam dan Kangkung berumur 45 hari maka petani sampel di lokasi penelitian sudah bisa mulai memanen sayuran. Adapun cara pemanenan Kangkung dan Bayam adalah dengan mancabut sampai ppada akarnya. Sebelum di pasarkan Bayam dan Kangkung di bersihkan dari tanah-tanah yang menempel di akar sayuran.

Budidaya sayur Sawi tidak jauh berbeda dengan budidaya Kangkung dan Bayam. Hanya saja pada budidaya sayur Sawi, benih di semai pada lahan tertentu dan setelah dua minggu bibit Sawi di tanam pada bedengan yang sudah dibiarkan seminggu. Pada umumnya petani menggunakan tenaga kerja tambahan untuk tahap penanaman Sawi. Adapun tahap perawatan Sawi sama di lakukan petani responden sebagaimana tahap perawatan ppada Bayam dan Kangkung.

Pemanenan Sawi dilakukan setelah Sawi berumur 40 hari setelah bibit Sawi di tanam.Pemanenan Sawi dilakukan dengan pemotongan pada ujung pangkal tanaman.Pada pemanenan petani responden pada umumnya juga menambah tenaga kerja luar keluarga.

\subsection{Deskriptif Karakteristik Modal Sosial Petani Sayur}

Modal sosial (social capital) merupakan aspek penting untuk membangun pertanian yang lebih maju.Dengan modal sosial yang berkembang di lingkungan petani kebersamaan petani menjadi kuat.Wujud dari modal sosial tersebut adalah bahwa petani memiliki kekerabatan kuat dalam meningkatkan daya saing komoditi pertanian yang dihasilkan.

Modal sosial yang terbentuk di lingkungan petani pada lokasi penelitian merupakan modal sosial yang tumbuh dan berkembang seiring dengan adanya kebutuhan petani untuk maju dan berkembang.Dengan demikian modal sosial yang terbentuk adalah bersifat dinamis. Sebagaimana Wuysang menyatakan bahwa modal sosial adalah serangkaian nilai dan norma yang merupakan wujud nyata dari suatu institusi yang bersifat dinamis. ${ }^{4}$ Modal sosial yang terbangun pada sebuah kelembagaan menjadikan individu yang di dalamnya memiliki ikatan yang kuat untuk saling menguntungkan. Bourdieu dalam Widodo menjelaskan bahwa modal sosial sebagai agregat sumberdaya actual ataupun potensial yang diikat untuk mewujudkan jaringan yang berjangka panjang (durable) sehingga menginstitusionalisasikan hubungan persahabatan (acquaintance) yang saling menguntungkan. ${ }^{8}$ Selanjutnya Widodo menyimpulkan bahwa modal sosial adalah modal yang dimiliki individu manusia yang mengacu pada perilaku yang kooperatif.

Karakteristik modal sosial dalam penelitian adalah; Partisipasi aktif petani sampel, Kepercayaan, Norma Sosial dan tanggung jawab. Adapun deskripsi dari modal sosial tersebut dapat ditunjukkan sebagai berikut:

\section{Partisipasi aktif petani sampel}

Partisipasi aktif petani sampel penelitian pada setiap kegiatan kelompok tani merupakan wujud dari adanya keinginan petani untuk saling menguatkan kekerabatan antar petani.Keinginan yang kuat dari anggota kelompok untuk tidak saja berpartisipasi tetapi senantiasa mencari jalan bagi keterlibatan anggota kelompok dalam suatu kegiatan masyarakat. Anggota kelompok melibatkan diri dan mencari kesempatan yang dapat memperkaya hubungan-hubungan sosial dan menguntungkan kelompok. Perilaku inisiatif dalam mencari informasi berbagai pengalaman, memperkaya ide, pengetahuan, dan beragam bentuk inisiatif lainnya baik oleh individu mapun kelompok, merupakan wujud modal sosial yang berguna dalam membangun masyarakat.

Tabel 3. Distribusi responden berdasarkan partisipasi aktif petani sampel

\begin{tabular}{llccc}
\hline \multicolumn{1}{c}{ No. } & Kelas skor & Kategori skor & Frekuensi & Persentase $(\%)$ \\
\hline 1 & Tinggi ( > rata-rata) & $\mathrm{T}$ & 17 & 56,7 \\
2 & Rendah ( < rata-rata) & $\mathrm{R}$ & 13 & 43,3 \\
& & & 30 & 100 \\
\hline
\end{tabular}


Dari Tabel 3. dapat diketahui bahwa petani responden penelitian memiliki partisipasi aktif tinggi lebih dominan yaitu 56,7 \% sementara yang memiliki partisipasi aktif rendah sebanyak 43,3\%. Pada saat di wawancara dengan petani responden diketahui bahwa pada umumnya responden memiliki persepsi yang bagus terhadap keberadaan kelompok tani.Petani responden tidak hanya bertemu dalam kegiatan kelompok tani tetapi mereka juga mengadakan perkumpulan yang disebut arisan.Kelompok arisan terbentuk dari petani sendiri sebagai wadah untuk mempererat persaudaraan sesama petani.Kegiatan arisan dilakukan dua bulan sekali dengan bergantian mengunjungi antar petani.

Petani responden menyadari bahwa kegiatan kelompok tani merupakan wadah bagi mereka untuk menambah pengetahuan dan wawasan dalam mengelola usaha tani.Responden juga menyadari bahwa kehadiran petani penting pada acara atau pertemuan yang dibuat oleh penyuluh pertanian.Disamping itu petani tidak hanya menghadiri saja tetapi mereka juga aktif dalam kegiatan dengan adanya komunikasi aktif mereka baik dalam memberi masukan ide-ide ataupun dalam bertanya dan berdiskusi.Hubungan baik yang terbangun tersebut di latar belakangi oleh adanya hubungan kekerabatan yang erat antar petani.Salah satu kunci keberhasilan membangun modal sosial terletak pula pada kemampuan sekelompok orang dalam suatu organisasi atau perkumpulan dalam melibatkan diri dalam suatu hubungan jaringan sosial. ${ }^{9}$

Partisipasi aktif petani responden juga terlihat dalam menyelesaikan permasalahanpermasalahan usaha tani mereka yang saling bergotong royong.Misalnya untuk membangun jembatan menuju ke lahan usaha tani, membuat

Tabel 4. Distribusi responden berdasarkan parit dan sebagainya.Keterlibatan petani untuk saling bekerjasama akan memudahkan mereka dalam menyelesaikan permasalahanpermasalaham. Sebagaimana menurut Brown dan Ashman dalam Claridge menyatakan partisipasi aktif dari seluruh elemen masyarakat dalam pemecahan suatu masalah sosial akan menghasilkan solusi yang lebih tepat. ${ }^{10}$ Pada proses tersebut seluruh elemen masyarakat berkumpul untuk menyelesaikan suatu masalah sosial yang didalamnya terdapat hubungan kerjasama, rasa saling percaya dan pertukaran gagasan.

\section{Kepercayaan Petani Sampel}

Kepercayaan merupakan karakteristik pertama yang harus terdapat pada sebuah kelompok.Kepercayaan pada sebuah kelompok merupakan modal untuk maju dan berkembangnya kelompok tersebut. Tanpa adanya kepercayaan antar satu anggota dengan anggota kelompok yang lain maka antara anggota akan saling mencurigai dan munculnya persaingan tidak sehat sehingga kelompok akan hancur.

Fukuyama mengemukakan bahwa kepercayaan adalah sikap yang saling mempercayai sehingga memungkinkan masyarakat untuk saling bersatu dengan yang lain dan memberikan kontribusi pada peningkatan modal sosial. ${ }^{4}$ Sementara Putnam menjelaskan bahwa trust atau rasa saling percaya adalah bentuk keinginan mengambil resiko dalam hubungan sosial yang didasari oleh munculnya perasaan yakin terhadap individu lain akan melakukan sesuatu sebagaimana yang diharapkan dan akan selalu pada tindakan yang saling mendukung dan tidak akan melakukan tindakan yang merugikan diri sendiri maupun kelompok. 5 Adapun distribusi respoden penelitian berdasarkan kepercayaan dapat ditunjukkan pada Tabel 4.

\begin{tabular}{llccc}
\multicolumn{2}{c}{ Kelas skor } & Kategori skor & Frekuensi & Persentase \\
\hline \multicolumn{2}{c}{ No. Distribusi responden berdasarkan Kepercayaan petani sampel } \\
\hline 1
\end{tabular}

Sumber: Data primer diolah tahun 2017

Berdasarkan Tabel 4. dapat diketahui bahwa kepercayaan yang terbangun pada responden penelitian dominan adalah memiliki kepercayaan tinggi sebanyak 56,6\% sedangkan kepercayaan rendah yaitu 43,4\%. Apabila kita perhatkan hasil yang diperoleh tersebut sama dengan deskripsi yang terdapat pada partisipasi aktif responden. Dengan demikian sebagaimana yang dikemukakan oleh Brown dan Ashman dalam Claridge menyatakan bahwa pada proses partisipasi aktif seluruh elemen masyarakat berkumpul untuk menyelesaikan suatu masalah 
sosial yang didalamnya terdapat hubungan kerjasama, rasa saling percaya dan pertukaran gagasan. ${ }^{10}$

Kepercayaan antar anggota kelompok tani menggambarkan bagaimana modal social yang terbangun pada kehidupan mesyarakat di lokasi penelitian.Dari wawancara dapat diketahui bahwa petani responden hidup dengan saling percaya tidak saling mencurigai atau saling bersaing secara negative. Sebagaimana yang di kemukakan oleh Hasbullah bahwa Kepercayaan merupakan salah satu elemen pokok yang akan menentukan apakah suatu masyarakat memiliki kekuatan modal sosial atau tidak. ${ }^{9}$ Unsur ini memiliki kekuatan penggerak energi kolektif yang sangat tinggi karena kepercayaan senantiasa dipandang penting.

Tabel 5. Distribusi responden berdasarkan Norma sosial petani sampel

\begin{tabular}{|c|c|c|c|c|}
\hline No. & Kelas skor & Kategori skor & Frekuensi & Persentase (\%) \\
& & & & \\
\hline 1 & Tinggi ( > rata-rata) & $\mathrm{T}$ & 24 & 80 \\
\hline 2 & Rendah ( r rata-rata) & $\mathrm{R}$ & 6 & 20 \\
\hline \multicolumn{2}{|c|}{ Jumlah } & 30 & 100 \\
\hline
\end{tabular}

Sumber: Data primer diolah tahun 2017

Berdasarkan Tabel 5. dapat diketahui

bahwa deskripsi dari norma sosial yang terdapat di lokasi penelitian adalah dominan responden penelitian memiliki norma sosial yang tinggi yaitu sebanyak $80 \%$ atau 24 responden memiliki norma sosial yang tinggi. Sedangkan 6 responden atau 20\% memiliki norma sosial yang rendah. Tingginya norma social yang terdapat pada kehidupan petani sampel merupakan implikasi dari masih tingginya kebiasaan hidup yang dilakukan petani sampel berdasarkan agama yang mayoritas beragama Islam dan juga aspek budaya. Misalnya pada saat di lokasi penelitian ada masyarakat yang mengalami musibah seperti meninggal dunia maka pada hari tersebut seluruh petani tidak ada yang turun ke lahan usaha tani. Petani dan masyarakat berkumpul di tempat warga yang terkena musibah sampai proses pemakaman selesai. Hal tersebut terjadi secara berkelanjutan. Sebagaimana yang dikemukakan oleh Fukuyama bahwa nilainilai social sebenarnya merupakan aturan tidak tertulis dalam sebuah sistem sosial

\section{Norma Sosial}

Norma sosial merupakan salah satu aspek dari modal sosial.Norma sosial adalah sekumpulan aturan yang diharapkan dipatuhi dan diikuti oleh masyarakat dalam suatu entitas sosial tertentu. Aturan-aturan ini biasanya terinstitusionalisasi, tidak tertulis tapi dipahami sebagai penentu pola tingkah laku yang baik dalam konteks hubungan sosial sehingga ada sangsi sosial yang diberikan jika melanggar. Norma sosial akan menentukan kuatnya hubungan antar individu karena merangsang kohesifitas sosial yang berdampak positif bagi perkembangan masyarakat. Adapun gambaran dari norma sosial yang terdapat pada petani responden penelitian sebagaimana pada Tabel 5 yangmengatur masyarakat untuk berperilaku dalam interaksinya dengan orang lain. ${ }^{4}$

\section{Tanggung jawab}

Tanggung jawab menurut Abdulkadir Muhammad adalah wajib, menanggung, wajib memikul beban, wajib memenuhi segala akibat yang timbul dari perbuatan, rela mengabdi, dan rela berkorban untuk kepentingan pihak lain. Dengan demikian tanggung jawab dapat dikatakan sebuah sikap dan perbuatan yang mau menanggung beban dan rela melakukan sesuatu sebagaimana yang ditujukan padanya. ${ }^{11}$

Tanggung jawab sosial sebagaimana yang dikemukakan oleh Wuysang adalah kesadaran akan pribadi terhadap prilakunya di dalam masyarakat. ${ }^{3}$ Dalam modal sosial tentu akan timbul pemahaman bahwa setiap anggota masyarakat tidak akan mungkin dapat hidup secara individu oleh karena itu ia hidup dalam kelompok atau masyarakat. Oleh karena itu hidup dalam kelompok tentu akan memiliki tanggung jawab sosial yang tinggi. Adapun deskripsi tanggung jawab responden dapat ditunjukkan pada Tabel 6 .

Tabel 6. Distribusi responden berdasarkan tanggung jawab petan sampel 6 .

\begin{tabular}{llccc}
\hline \multicolumn{2}{c}{ Ko. Kelas skor } & Kategori skor & Frekuensi & Persentase $(\%)$ \\
\hline 1 & Tinggi ( > rata-rata) & $\mathrm{T}$ & 20 & 66,7 \\
2 & Rendah ( > rata-rata) Jumlah & $\mathrm{R}$ & 10 & 33,3 \\
& \multicolumn{2}{c}{ Jum } & 30 & 100
\end{tabular}

Sumber: Data primer diolah tahun 2017

Tabel 6. menunjukkan bahwa responden dengan tanggung jawab tinggi sebanyak 20 orang atau $66,7 \%$ dan yang 


\section{KAJIAN MODAL SOSIAL PADA USAHA TANI SAYUR}

memiliki tanggung jawab dalam bermasyarakat.Tanggung jawab yang tinggi tersebut ditunjukkan oleh kesadaran petani sampel dalam membayar iuran anggota kelompok maupuan dalam membayar iuran arisan.Mereka menyadari bahwa hal itu merupakan tanggung jawab mereka untuk menjaga keberlanjutan kegiatan di kelompok tani. Dengan majunya kegiatan di kelompok tani maka mereka juga akan mengalami kemajuan baik wawasan, pengetahuan dan pendapatan. Seagaimana yang dikemukakan Wuysang tanggung jawab sosial adalah kesadaran akan pribadi terhadap prilakunya di dalam masyarakat. ${ }^{3}$

\section{KESIMPULAN DAN SARAN}

Modal sosial yang terbentuk di lingkungan petani pada lokasi penelitian merupakan modal sosial yang tumbuh dan berkembang seiring dengan adanya kebutuhan petani untuk maju dan berkembang. Adapun hasil penelitian menunjukkan bahwa seluruh aspek yang di analisis pada modal social yang terdiri dari partisipasi aktif, kepercayaan, norma social dan tanggung dominan adalah tinggi. Dengan demikian modal social yang terdapat pada kelompok tani Barokah yang merupakan sampel penelitian merupakan modal social yang membangun untuk pengembangan pertanian di lokasi penelitian.

\section{DAFTAR PUSTAKA}

1 BPS.Kota Medan. 2011.

2 Endang dan Harahap, Mailina.Economic Diversity and Marketing Pattern of Vegetable Farm Business in District of Medan Marelan. Jurnal Ilmu Pertanian Agrium. UMSU.Vol. 19.No.3 Tahun 2015.

3 Wuysang, Rendy. 2014. Modal Sosial Kelompok Tani Dalam Meningkatkan Pendapatan Keluarga Suatu Studi Dalam Pengembangan Usaha Kelompok Tani Di Desa Tincep Kecamatan Sonder. Jurnal Acta Diurna. Vol. III. No. 3.

4 Fukuyama Prancis. 2001. Social Capital. Civil Society and Development WordQuarttlerly.

5 Putnam, Robert. 2003. Bowling Alone: The Collapse and revival of American Community. New York: Simon and Schester, ISBN 9780684832838.

6 Desi Utami, 2014.

7 Soekanto, 2003

8 Widodo, Kunto. 2015. Analisis Pengaruh Modal Sosial terhadap Produktivitas Lahan Jagung. Studi Kasus Kecamatan Pulo Kulon, Kabupaten Grobongan. Skripsi Fakultas Ekonomi dan Bisnis. Universitas Diponegoro, Semarang.

9 Hasbullah, J. 2006. Sosial Kapital: Menuju Keunggulan Budaya Manusia Indonesia. Jakarta: Mr. United States.

10 Ashman dalam Claridge, 2004.

11 Abdulkadir Muhammad, 2000.

12 Hanafie, Rita. 2010. Pengantar ekonomi Pertanian. Andi offset. Yogyakarta. 